\title{
ANTIBACTERIAL EFFECT OF FOUR IRRIGATING SOLUTIONS COMPARED TO THAT OF SODIUM HYPOCHLORITE (A COMPARATIVE IN-VITRO STUDY)
}

\author{
Ali Adel Arab*, Maged Mohamed Negm** and Salwa Ibrahim Youssef ${ }^{* * *}$
}

\begin{abstract}
Aim : The aim of the present study was to evaluate the antimicrobial activity of four irrigating solutions against Enterococcus faecalis compared with sodium hypochlorite 5.25\% namely: propolis extract, QMix, Chloroxylenol and CHX-Plus.

Materials and methods: Enterococcus faecalis (batch no. 10541) thawed and incubated under aerobic condition. The harvested bacterial colonies are then spectrophotometrically calibrated to 5.9 x 104 (CFU/mL-1). Fifty specimens instrumented conventionally, reaching master apical file size $\# 50$. Twenty $\mu \mathrm{L}$ of the bacterial culture transferred to the canal lumen using sterile micropipette. All specimens were then incubated for 48 hours at $37{ }^{\circ} \mathrm{C}$.
\end{abstract}

Results : Intracanal sample collection by paper points showed an insignificant difference between different irrigation solutions tested and positive control Group at $\mathrm{p}=0.001$. Group 1 showed a median of $8.9^{*} 10^{4}(\mathrm{CFU} / \mathrm{ml})$, where group 2,3,4 and positive control groups showed mean values of $2.2^{*} 10^{4}, 7.3 * 10^{4}, 8 * 10^{4}$ and $3 * 10^{4}(\mathrm{CFU} / \mathrm{ml})$ respectively. Negative control group showed the highest significant values for colony forming units $\left(118.4 * 10^{4} \mathrm{CFU} / \mathrm{ml}\right)$.

Conclusion : All groups except the saline produce of significant reduction of bacteria. Although QMix, $\mathrm{NaOCl}$ and chlorhexidine plus are capable of reducing bacterial count their effect is statistically insignificant.

KEYWORDS: Enterococcus faecalis,QMix, propolis extract, CHX-Plus, Chloroxylenol, $\mathrm{NaOCl} 5.25 \%$.

\section{INTRODUCTION}

Bacteria and their products play an essential role in the development and perpetuation of pulpal and periradicular diseases. Although the root canal flora is dominated by obligate anaerobic bacteria, some facultative strains, e.g. Enterococcus faecalis, have been involved in persistent infections, influencing the prognosis of the root canal treatment. Once bacteria are established in the root canal, they cannot easily

\footnotetext{
* Research Postgraduate Student.

** Professor of Endodontics, Faculty of Oral and Dental Medicine, Cairo University.

*** Lecturer of microbiology, Faculty of Dentistry, October 6 University.
} 
be reached by the defense mechanisms of the host. Hence, irrigation during an endodontic treatment serves several purposes such as canal lubrication; dissolving pulp tissue, mechanical washing out of debris created by canal instrumentation, eradication of microorganisms from the root canal. Sometimes an infection is resistant to normal treatment, and the therapy cannot be successfully completed. Therefore, a search for better root canal irrigant continues.

\section{MATERIAL AND METHODS}

\section{Selection and preparation of teeth}

Fifty recently extracted human lower single canalled first premolars were used in this study. Access cavity was prepared to gain access. Canals were then instrumented, coronal one third of the canals was enlarged with Gates Glidden drills sizes \# 2, 3 and 4.Teeth were then prepared up to size 50 k-file $1 \mathrm{~mm}$ shorter from the apical foramen. During instrumentation the root canals were irrigated with saline between successive files. The apical foramen was sealed with resin restoration to prevent bacterial leakage.

Teeth were horizontally decapitated at the level of cemento-enamel junction. Sterilization of the samples after complete root canal cleaning and shaping was achieved by autoclaving for $30 \mathrm{~min}$ at $121{ }^{\circ} \mathrm{C}$ pressure 15 Psi.

\section{Selection and preparation of bacteria}

A pure bacterial culture of Enterococcus faecalis (ATCC 10541) was obtained, the frozen bacterial samples $\left(-20^{\circ} \mathrm{C}\right)$ were thawed and incubated for 24 hours on a solid culture medium (Brain Heart Infusion Agar, supplemented with 7\% sheep blood) $37^{\circ} \mathrm{C}$ under aerobic conditions. The grown bacterial colonies were then harvested, placed in MuellerHinton nutrient broth and incubated for an additional 24 hours at $37^{\circ} \mathrm{C}$ under aerobic conditions.
The Enterococcus faecalis cultures were then calibrated to $5.9 \times 10^{4}$ colony forming units per $\mathrm{ml}$ (CFU ml) spectrophotometrically in Muller-Hinton broth. Twenty $\mu 1$ of the bacterial culture were transferred to the canal lumen of the mechanically enlarged root canals using sterile micropipette and then stored for 48 hours at $37^{\circ} \mathrm{C}$ in the incubator.

\section{Specimens classification}

After the 48 hours incubation period the specimens were then divided into five groups; 10 specimens each;

Group 1: Specimens $(n=10)$ were irrigated with propolis ( $2 \mathrm{ml}$ per specimen).

Group 2: Specimens $(n=10)$ were irrigated with QMix (2 ml per specimen).

Group 3: Specimens $(n=10)$ were irrigated with chloroxylenol ( $2 \mathrm{ml}$ per specimen).

Group 4: Specimens $(n=10)$ were irrigated with chlorhexidine plus ( $2 \mathrm{ml}$ per specimen).

Group 5: Positive control: Specimens $(n=5)$ were irrigated with $5.25 \%$ sodium hypochlorite ( $2 \mathrm{ml}$ per specimen). Negative control: Specimens $(n=5)$ were irrigated with physiological saline (2 $\mathrm{ml}$ per specimen).

\section{Specimens irrigation}

All procedures were conducted inside a laminar flow chamber using sterile instruments to avoid contamination. The irrigating solutions were kept inside the canals for a period of $1 \mathrm{~min}$ then irrigated with saline.

Thereafter, a sterile paper point \# 50 was inserted into each canal and maintained for $1 \mathrm{~min}$. for sample collection. The paper point of each group was individually transported to test tubes containing $2 \mathrm{ml}$ of sterile saline then vortexed for 20 seconds.

A calibrated loop $10 \mu \mathrm{L}$ of each tube was adjusted and placed in Mueller-Hinton agar culture plates and incubated at $37^{\circ} \mathrm{C}$ for 48 hours. Aclassical bacterial counting technique was used for 
each group for the recovery of viable Enterococcus faecalis on Mueller-Hinton agar plates. The mean value of CFU for the plates of each group was then calculated.

\section{Statistical analysis}

Statistical analysis was performed with IBM ${ }^{\circledR}$ SPSS ${ }^{\circledR}$ (SPSS Inc., IBM Corporation, NY, USA) Statistics Version 21 for Windows. Colony forming units were transferred using log transformation before statistical analysis. A non-parametric one-way ANOVA (Kruskal-Wallis) test followed by paired group comparisons using the Mann-Whitney U test at a 5\% significance level were used to analyze the effect of different irrigant types on colony forming units. Mann-Whitney U test was used to test the difference between negative and positive controls.

\section{RESULTS}

\section{Difference between different irrigations used and positive and negative control groups on Bio- film Susceptibility:}

A non-parametric one-way ANOVA (KruskalWallis) test showed an insignificant difference between different irrigation solutions tested and positive control Group at $\mathrm{p}=0.001$. Group 1 showed a median of $8.9 * 10^{4}(\mathrm{CFU} / \mathrm{ml})$, where group 2, 3, 4 and positive control groups showed mean values of $2.2 * 10^{4}, 7.3 * 10^{4}, 3.5^{*} 10^{4}$ and $3 * 10^{4}$ $(\mathrm{CFU} / \mathrm{ml})$ respectively. Negative control group showed the highest significant values for colony forming units $\left(118.4 * 10^{4} \mathrm{CFU} / \mathrm{ml}\right)$, as shown in Table 1.

TABLE (1) Comparison between different irrigating groups and the control groups.

\begin{tabular}{|c|c|c|c|c|c|c|c|c|}
\hline & & \multicolumn{6}{|c|}{ Group } & \multirow[b]{2}{*}{ p-value } \\
\hline & & $\begin{array}{l}\text { Group } 1 \\
\text { (Propolis) }\end{array}$ & $\begin{array}{l}\text { Group } 2 \\
\text { (Qmix) }\end{array}$ & $\begin{array}{c}\text { Group } 3 \\
\text { (Chloroxylenol) }\end{array}$ & $\begin{array}{c}\text { Group } 4 \\
\text { (Chlorhexidine } \\
\text { plus) }\end{array}$ & $\begin{array}{c}\text { Group } 5 \\
\text { (+Ve Control) } \\
(5.25 \% \\
\mathrm{NaOCl}) \\
\end{array}$ & $\begin{array}{c}\text { Group } 6 \\
\text { (-Ve Control) } \\
\text { (Saline) }\end{array}$ & \\
\hline \multirow{5}{*}{$\begin{array}{l}\text { Colony } \\
\text { forming unit } \\
(\mathrm{CFU} / \mathrm{ml})\end{array}$} & Mean & $8.9 * 10^{4}$ & $2.2 * 10^{4}$ & $7.3^{*} 10^{4}$ & $3.5^{*} 10^{4}$ & $3 * 10^{4}$ & $118.4^{*} 10^{4}$ & \multirow{5}{*}{$0.001 *$} \\
\hline & SD & $8 * 10^{4}$ & $6.9 * 10^{4}$ & $15^{*} 10^{4}$ & $2.3^{*} 10^{4}$ & $6.7 * 10^{4}$ & $19.6 * 10^{4}$ & \\
\hline & Minimum & 0.0 & 0.0 & 0.0 & 0.0 & 0.0 & $94 * 10^{4}$ & \\
\hline & Maximum & $21 * 10^{4}$ & $22 * 10^{4}$ & $40 * 10^{4}$ & $45^{*} 10^{4}$ & $15^{*} 10^{4}$ & $147 * 10^{4}$ & \\
\hline & Rank & A & A & A & $\mathrm{A}$ & A & B & \\
\hline
\end{tabular}

Means with the same letters within each row are not significantly different at $p=0.05 . \quad *=$ Significant

\section{DISCUSSION}

The results obtained from this study indicated that there was a statistically significant reduction in the mean values of the bacterial count after the application of the allocated treatment for each group when compared with saline (negative group).
The physiological saline lacks any antibacterial properties. In addition it serves as an indicator to the incubation process and the ability of the microorganisms to grow. Also it provides a standard in which the performance of other irrigants are compared. 
Results of the present study showed that the QMix has the highest percentage of mean value of bacterial count reduction, with no significant difference between other groups except saline. QMix irrigant and its modifications containing a mixture of a bisbiguanide antimicrobial agent, a polyaminocarboxylic acid calcium-chelating agent, saline, and a surfactant have been found to be more effective than BioPure MTAD against bacterial biofilms ${ }^{(1)}$. A surface-active agent decreases the surface tension of solutions and increases their wettability ${ }^{(2)}$. Also, it enables better penetration of an irrigant into the root canal that coincide with Stojicic et al ${ }^{(3)}$, Morgental et al ${ }^{(4)}$ and Wang et $\mathrm{al}^{(5)}$. Abidal et al ${ }^{(6)}$ demonstrated that the addition of a surfactant to EDTA and CHX in the composition of QMix may have accounted for its potent antimicrobial efficacy. Arias-Molizetal (7) showed that the association of a surfactant (cetrimide) to CHX provided better results than their application as single agents against E. faecalis. Furthermore, EDTA is regarded as a potentiator of the activity of other antimicrobial agents ${ }^{(8)}$.

Followed by the QMix, $\mathrm{NaOCl}$ showed high percentage of bacterial count reduction while the difference between $5.25 \% \mathrm{NaOCl}$ and QMix was not statistically significant that corroborate with Ma et al ${ }^{(9)}$, Sodium hypochlorite also has a potent antibacterial efficiency due to its excellent organic tissue solvent (10) and sodium also effective in aiding the mechanical flushing of debris from root canal ${ }^{(11)}$. Previous study investigated that sodium hypochlorite has been recommended as an irrigant solution in the treatment of infected root canals, because of its well-known bactericidal action ${ }^{(12,13)}$. On the contrary, Lekshmy et al (14), Menezes et al ${ }^{(15)}$ and Ahangari et al ${ }^{(16)}$ observed that $\mathrm{NaOCl}$ is a weak antibacterial irrigant in comparison with the other irrigants, this discrepancy might be related to the difference in the concentration as this study was done at concentration of $5.25 \%$ while others used $2.5 \%$ concentration.
Chlorhexidine, came next to $\mathrm{NaOCl}$ with also no statistically significant difference with both QMix and $\mathrm{NaOCl}$ as mentioned with Heling and Chandler ${ }^{(17)}$. The antimicrobial effect of CHX is mediated by several mechanisms. It binds electrostatically to negatively charged sites on bacteria. CHX causes the osmotic balance to be lost, resulting in leakage of intracellular material. It also binds to hydroxyapatite and soft tissues, changing their electrical field to compete with bacterial binding ${ }^{(17)}$. Surfactant have been added, as it increases the efficiency of an endodontic irrigant by reducing its surface tension and increasing the fluid flow over the debris on the root canal walls ${ }^{(18)}$. In other words, if a root canal irrigant can easily spread over a dentine surface, irrigation efficiency may improve. Also, once a given dentine surface has been treated with one irrigant, the spreading of another irrigant would change ${ }^{(19)}$. However, Wang et al ${ }^{(20)}$ reported that six percent $\mathrm{NaOCl}$ and QMix had stronger antibacterial effects against young and old $\mathrm{E}$. faecalis biofilms in dentin than $2 \% \mathrm{NaOCl}$ and $2 \% \mathrm{CHX}$. The difference between the results of Wang et al ${ }^{(20)}$ and the present investigation can be explained by the fact that the present investigation was done on planktonic bacteria whereas their studies were done on bacterial biofilms.

Next in effect came chloroxylenol showing a statistically significant reduction in the mean values of the bacterial count but was statistically insignificant with other groups except saline. Chloroxylenol efficient antimicrobial effect is due to the mechanism of antimicrobial action which occurs by the disruption of cell membranes by preventing the uptake of essential amino acids ${ }^{(21)}$. Also likely, this agent, as for other phenolic compounds, may act on the cytoplasmic membranes, producing leakage and disruption of membrane transport ${ }^{(22)}$. Although the difference between chloroxylenol and other irrigants was statistically insignificant but it was weaker than QMix, $\mathrm{NaOCl}$ and chlorhexidine plus. This was consistent with Schafer and Bossmann ${ }^{(23)}$ who demonstrated that there were no 
significant differences between the antimicrobial activity of chlorhexidine $2 \%$ and chloroxylenol $10 \%$. In contrast Aly and Maibach ${ }^{(24)}$ observed that the use of chlorhexidine achieved significantly greater adjusted mean log bacterial count reduction than chloroxylenol at all samples. This discrepancy might be related to the different bacterial type with different media and technique.

The present results led to the conclusion that propolis is effective against $E$. faecalisafter biomechanical preparation. However, it was weaker than other groups though statistically insignificant. It is a potent antimicrobial, antioxidant, and antiinflammatory agent. The main chemical elements present in propolis are flavonoids, phenolics, and various aromatic compounds. Flavonoids are wellknown plant compounds that have antioxidant, antibacterial, antifungal, antiviral, and antiinflammatory properties ${ }^{(25)}$. Some components present in propolis extract, like flavonoids (quercetin, galangin, pinocembrin) and caffeic acid, benzoic acid, cinnamic acid, probably act on the microbial membrane or cell wall site, causing functional and structural damage. Many properties have been described for propolis, including antibacterial, antiviral, antifungal, and antiprotozoan activities ${ }^{(26-29)}$. The antibacterial activity of propolis is variable, which depends primarily on its origin due to its flavonoids contents $(30,31,32)$. However, irrigation with propolis glycolic extract was not effective enough to neutralize the endotoxins ${ }^{(33)}$. For this reason, it is not possible to report the exact microbial activity of very well defined composition of propolis theoretically ${ }^{(32)}$. The present study coincides with Carbajal Mejia (34) who demonstrated that there was no significant difference between CHX and propolis in reducing $E$. faecalis. On the contrary Kandaswamy ${ }^{(35)}$ observed that chlorhexidine has better antimicrobial efficacy than propolis. This controversy can be explained by the fact that there is difference in time of the irrigation as he kept the irrigant in the canals for one, three and five days.

\section{CONCLUSIONS}

All groups except the saline produce significant reduction of bacteria. Although QMix, $\mathrm{NaOCl}$ and chlorhexidine plus are capable of reducing bacterial count their effect is statistically insignificant.

\section{REFERENCES}

1. Dai L, Khechen K, Khan S, Gillen B, Loushine BA, Wimmer CE, Gutmann JL, Pashley D, Tay FR. The effect of QMix, an experimental antibacterial root canal irrigant, on removal of canal wall smear layer and debris. J Endod 2011; 37: 80-4.

2. Abou-Rass M, Patonai Jr FJ. The effects of decreasing surface tension on the flow of irrigating solutions in narrow root canals. Oral Surg 1982; 53: 524-6.

3. Stojicic S, Shen Y, Qian W, Johnson B, Haapasalo M. Antibacterial and smear layer removal ability of a novel irrigant, QMiX. Int Endod J 2012; 45: 363-71.

4. Morgental RD, Singh A, Sappal H, Kopper PM, VierPelisser FV, Peters OA. Dentin inhibits the antibacterial effect of new and conventional endodontic irrigants. J Endod 2013; 39: 406-10.

5. Wang Z, Shen Y, Haapasalo M. Evaluate the effect of smear layer against disinfection protocols on Enterococcus faecalis-infected Dentin. J Endod 2013; 39: 1395-400.

6. Abidal AA, Abdul-Rahman GY, Tawfeeq AW. The antibacterial effect of QMix, a novel root canal irrigant (ex vivo study). Al - Rafidain Dent J 2013; 13: 537-46.

7. Arias-Moliz MT, Ferrer-Luque CM, Gonzalez-Rodriguez MP, Valderrama MJ, Baca P. Eradication of Enterococcus faecalis biofilms by cetrimide and chlorhexidine. J Endod 2010; 36: 87-90.

8. Brown MR, Richards RM. Effect of ethylenediaminetetraacetate on the resistance of Pseudomonas aeruginosa to antibacterial agents. Nature 1965; 25: 1391-3.

9. Ma J, Wang Z, Shen Y. A new noninvasive model to study the effectiveness of dentin disinfection by using confocal laser scanning microscopy. J Endod 2011; 37: 1380-5.

10. Yamaguchi M, Yoshida K, Suzuki R, Nakamura H. Root canal irrigation with citric acid solution. J Endod 1996; 22: 27-9.

11. Radcliffe CE, Potouridou L, Qureshi R, Habahbeh N, Qualtrough A, Worthington H, Drucker DB. Antimicrobial activity of varying concentrations of sodium hypochlorite on the endodontic microorganisms Actinomyces Israelii, 
A. naeslundii, Candida albicans and Enterococcus faecalis. Int Endod J 2004; 37: 438-46.

12. Siqueira JF, Machado AG, Silveira RM, Lopes HP, De Uzeda M. Evaluation of the effectiveness of sodium hypochlorite used with three irrigation methods in the elimination of Enterococcus faecalis from the root canal, in vitro. Int Endod J 1997; 30: 279-82.

13. Nikolaus BE, Wayman BE, Encinas E. The bactericidal effects of citric acid and sodium hypochlorite on anaerobic bacteria. J Endod 1988; 14: 31-4.

14. Lekshmy DS and Kamath PM. Antimicrobial efficacy of $0.2 \%$ and $2 \%$ chlorhexidine and sodium hypochlorite as root canal irrigants: An in vivo study. Endodontology 2001; 13: 57-62.

15. Menezes MM, Valera MC, Jorge OC, Koga-Ito CY, Camargo $\mathrm{CH}$, Mancini MN. In vitro evaluation of the effectiveness of irrigants and intra canal medicaments on microorganisms within root canal. Int Endod J 2004; 37: 311-9.

16. Ahangari Z, Samiee M, Yolmeh MA, Eslami G. Antimicrobial activity of three root canal irrigants on Enterococcus faecalis: An in vitro study. Iran Endod J 2008; 3: 33-7.

17. Heling I and Chandler NP. Antimicrobial effect of irrigant combinations within dentinal tubules. Int Endod J 1998; 31: 8-14.

18. Torabinejad M, Khademi AA, Babagoli J. A new solution for the removal of the smear layer. J Endod 2003; 29: 170-5.

19. Marending M, Luder HU, Brunner TJ, Knecht S, Stark WJ, Zehnder M. Effect of sodium hypochlorite on human root dentine- mechanical, chemical and structural evaluation. Int Endod J 2007; 40: 786-93.

20. Wang Z, Shen Y and Haapasalo M. Effectiveness of endodontic disinfecting solutions against young and old Enterococcus faecalis biofilms in dentin canals. J Endod 2012; 38: 1376-9.

21. Zinn J, Jenkins JB, Swofford V, Harrelson B, Mccarter S. Intraoperative patient skin prep agents: is there a difference. AORN Journal 2010; 92: 662-74.

22. Simoni AY, Ihejirika KA, Ogunkoya AB, Hassan AZ, Adawa DAY, Adeyanju JB. Comparison of the antimicrobial efficacy of topical antiseptic creams on canine wounds (preliminary communication). Bulg J Vet Med 2007; 10: 273-81.

23. Schäfer E and Bossmann K. Antimicrobial efficacy of chloroxylenol and chlorhexidine in the treatment of infected root canals. Am J Dent 2001; 14: 233-7.
24. Aly R and Malbach HL. Comparative antibacterial efficacy of a 2-minute surgical scrub with chlorhexidine gluconate, povidone-iodine, and chloroxylenol spongebrushes. Infection Control 1988; 16: 173-7.

25. Opikrishna V, Baweja PS, Venkateshbabu N, Kandaswamy D. Comparison of coconut water, propolis, HBSS, and milk on PDL cell survival. J Endod 2008; 34: 587-9.

26. Marcucci MC. Propolis: chemical composition, biological properties and therapeutic activity. Apidologie 1995; 26: 83-99.

27. Cook NC and Samman S. Flavonoids - chemistry, metabolism, cardio protective effects and dietary sources. Nutr. Biochem 1996; 7: 66-76.

28. Gatto MT, Falcocchio S, Grippa E, Mazzanti G, Battinelli L, Nicolosi G, Lambusta D, Saso L. Antimicrobial and anti-lipase activity of quercetin and its C2-C163-O-acylesters. Bioorg. Med. Chem. 2002; 10: 269-72.

29. Mirzoeva OK, Grishanin RN, Calder PC. Antimicrobial action of propolis and some of its components: the effects on growth, membrane potential and motility of bacteria. Microbiol. Res 1997; 152: 239-46.

30. Hegazi AG and El Hady FK. Egyptian propolis: 1-Antimicrobial activity and chemical composition of upper Egypt propolis. Z Naturforsch C 2001; 56: 82-8.

31. Kosalec I, Pepeljnjak S, Bakmaz M, Vladimir-Knezević S. Flavonoid analysis and antimicrobial activity of commercially available propolis products. Acta Pharm 2005; 55: 423-30.

32. Koru O, Toksoy F, Acikel CH, Tunca YM, Baysallar M, Guclu AU, Akca E, Tuylu AO, Sorkun K, Tanyuksel M, Salih B. In vitro antimicrobial activity of propolis samples from different geographical origins against certain oral pathogens. Anaerobe 2007; 13: 140-5.

33. Valera MC, da Rosa JA, Maekawa LE, de Oliveira LD, Carvalho CA, Koga-Ito CY, Jorge AO. Action of propolis and medications against Escherichia coli and endotoxin in root canals. Oral Surg Oral Med Oral Pathol Oral Radiol Endod 2010; 110: 70-4.

34. Carbajal Mejía JB. Antimicrobial effects of calcium hydroxide, chlorhexidine, and propolis on Enterococcus faecalis and Candida albicans. J Investig Clin Dent 2014; 5: 194-200.

35. Kandaswamy D, Venkateshbabu N, Gogulnath D, Kindo AJ. Dentinal tubule disinfection with $2 \%$ chlorhexidine gel, propolis, morindacitrifolia juice, $2 \%$ povidone iodine and calcium hydroxide. IntEndod J 2010; 43: 419-23. 